
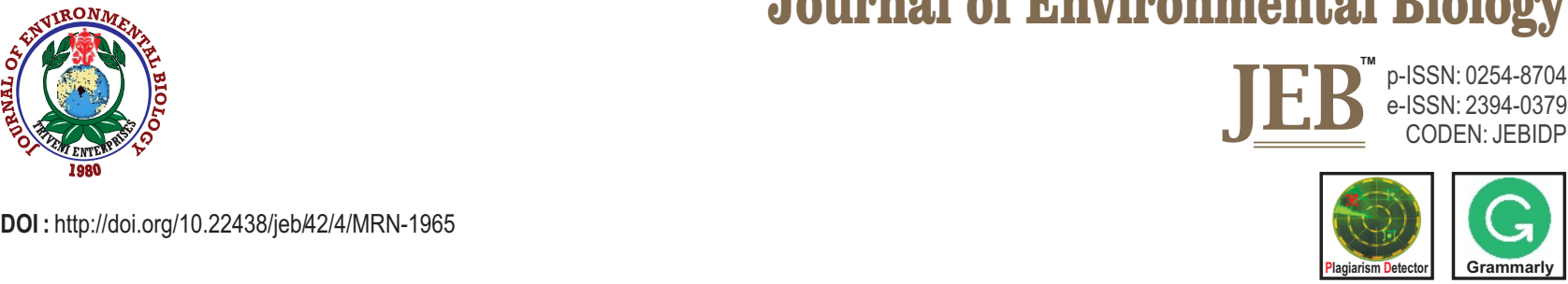

\title{
Mechanistic paradigms of cell death - revisited
}

\author{
S.V.S. Rana \\ Department of Toxicology, Ch. Charan Singh University, Meerut-250 004, India \\ *Corresponding Author Email : sureshvs_rana@yahoo.com
}

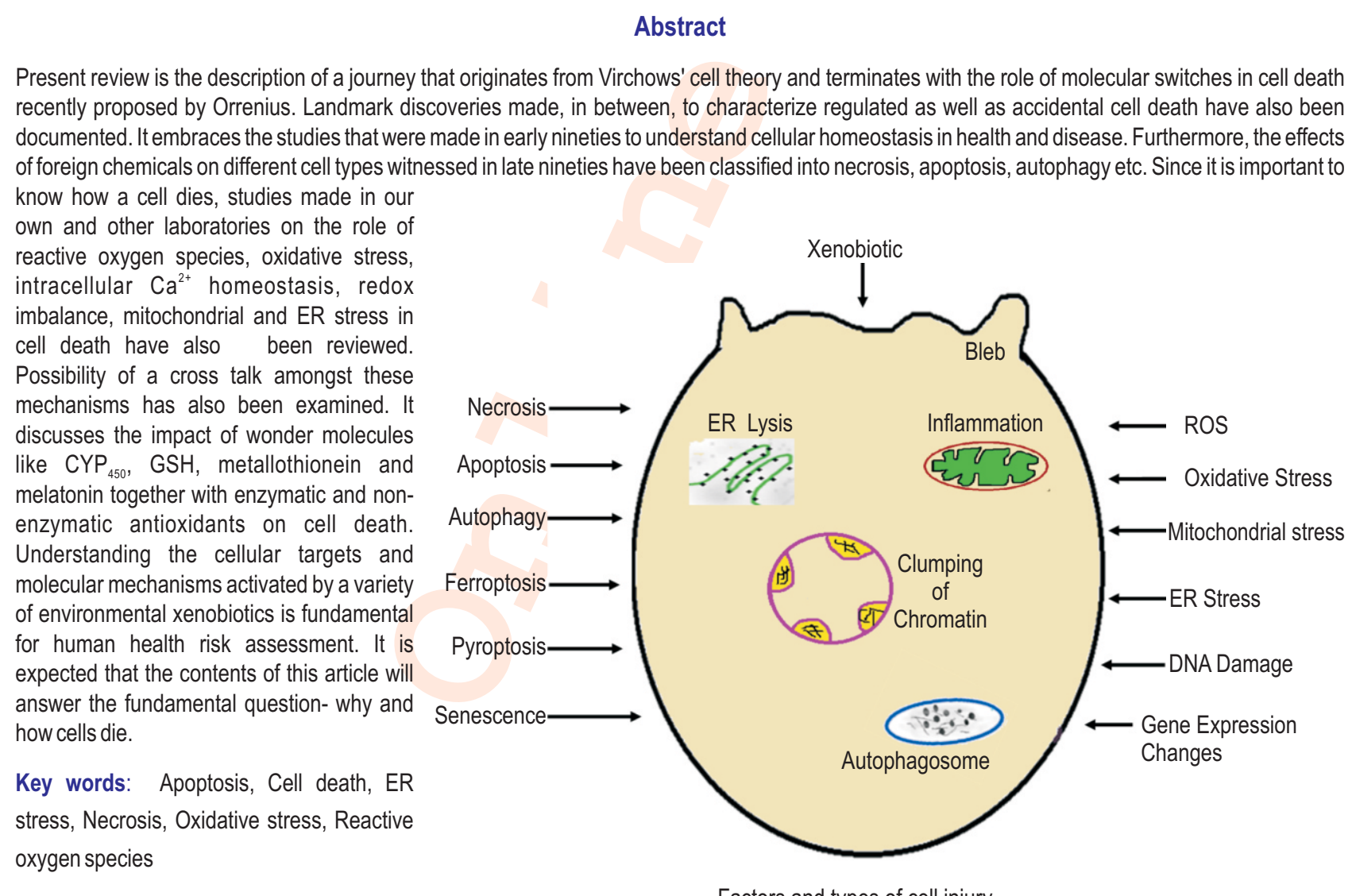

Factors and types of cell injury

How to cite : Rana, S.V.S.: Mechanistic paradigms of cell death - revisited. J. Environ. Biol., 42, 903-917 (2021). 


\section{Introduction}

Cell was first discovered and described by Robert Hooke in his book "Micrographia" in 1665. Anton van Leeuwenhoek was another scientist who saw the cells in 1676. Cell theory was proposed by two scientists Theodor Schwann and Matthias Jacob Schleiden in 1839. A German Physician Rudolph Ludwig Carl Virchow (1858) further added a third tenet to cell theory that postulated "Omnis cellula e cellula", literally meaning - every cell stems from pre-existing cell. In subsequent years Virchow made cellular pathology a subject of overwhelming importance. He delivered 20 lectures that were published in, "Cellular Pathology as based upon Physiological and Pathological Histology", a classical work that transformed scientific thought of cell biology. Another benchmark publication," Introduction to the Study of Experimental Medicine", by Claude Bernard (1865) introduced the term cellular homeostasis. Thereafter, the concepts of cell injury /cell death were considered fundamental to study the pathogenesis of disease. Several breakthroughs exploded between 1850s and 1950s. These included the discovery of nucleus (Robert Brown, 1831); mitochondria (Kolliker, 1857), golgi (Golgi,1898); structure of DNA( Watson and Crick, 1952-53) and endoplasmic reticulum (Keith Porter,1953). American Society of Cell Biology, celebrated 40 years of its inception and published landmark papers in cell biology in 2000. Discovery of immortal HeLa Cells (1951); DNA polymerase (1956); transmission electron microscope (1939) and PCR (1983) influenced research activities on cell, all over the globe. I am a witness to many researches that were focused to find an answer to the question-how cells die? Some of these answers are reported in this article. What little contribution could be made by me and my colleagues to address this question during five decades (1970-2020) is also described.

The process of cell death raises basic questions on creation and maintenance of an organism. Cell death is required to create an order in the organism. We do know that cells die in a controlled manner. The role of cell death in embryonic development has been recognized since $19^{\text {th }}$ century when embryologists recognized the basis of sexual differentiation, formation of complex structures such as limbs and disappearance of vestigial organs. Till (1981) classified cellular events of development in two categories. Lamarckian development- suggests the role of environment in the modification of genome. Whereas Darwinian concept proposes the role of gene expression in life or death of a cell. Both these processes create an order in cellular differentiation and homeostasis in embryonic life. Michaelson (1987) hypothesized that cell death is more a cause than result of developmental organization. Superfluous, irreversibly damaged or potentially harmful cells need to be removed by suitable intrinsic mechanisms (Conrad et al., 2016). Regulated cell death (RCD) occurs not only in multi-cellular organisms but has also been reported in several yeast species, Dictyostelium discoideum and in prokaryotes like Escherichia coli (Cornillon et al. 1998; Eisenberg et al. 2007). In contrast, accidental cell death (ACD) is instantaneous and catastrophic demise of cells that occurs in organisms/systems exposed to physical, chemical and/or mechanical stress. Different types of RCD and ACD can be separated in three types.

Types of cell death : Historically, cell death has been classified on the basis of a spectrum of morphological changes in the cells. Nomenclature Committee on Cell Death (Galluzzi et al., 2018) classified them into three categories-

Type I cell death : it includes apoptosis exhibiting cytoplasmic shrinkage, chromatin condensation (pycnosis), nuclear fragmentation (karyorrhexis) and membrane blebbing.

Type II cell death : It includes autophagy showing extensive cytoplasmic vacuolation, phagocytic uptake and consequent lysosomal degradation.

Type III cell death : It includes necrosis exhibiting no distinctive features of type-I and type - II cell death. Cell corpses are disposed without phagocytic and lysosomal involvement.

Present article reviews advances made in understanding necrosis, necroptosis, apoptosis, autophagy, ferroptosis, pyroptosis, parthanatos and senescence.

Necrosis : Our interest in necrotic cell death perhaps emerged in 1970s. A chapter entitled," Experimental Toxic Injury of the Liver", written by Professor Rouiller who edited "The Liver, Morphology, Biochemistry and Physiology, Part I and II (Academic Press London and New York) introduced this term necrosis. It has been derived from a Greek word ,"nekrosis" meaning cell injury that results in premature death of the cell due to autolysis. It was realized that different pathological conditions viz. hypoxia, trauma, exposure to toxins, ischemia, viral or bacterial infection and neurodegenerative disorders can induce necrotic cell death (Fig. 1). Morphologically, necrosis can be classified as coagulative necrosis, liquefactive necrosis, caseous necrosis, fat necrosis and fibrinoid necrosis. Pathogenesis of cell injury may be sublethal with chances of recovery or cell may pass through a phase of "no return". Phase of reversible injury exhibits hydropic degeneration, cloudy swelling or vacuolar degeneration (Rouiller, 1964; Popper and Schaffner, 1957; Arias et al., 1988; Zimmerman, 1978). In the late stage of necrosis, cytoplasm loses contents and exhibits homogeneous eosinophilic appearance, membrane changes, mitochondrial swelling, formation of vacuoles and deposition of calcium (Farber, 1982; Plaa, 2000). Contributors on liver cell necrosis were deliberated during a symposium," International Meeting On Recent Advances In Biochemical Pathology. Toxic Liver Injury" held at Turin, Italy. These researches were published and edited by Dianzani et al., (1975). Reversal of cell injury using suitable 
therapeutic agents was main focus of experimental biologists in 1980s. Lockard et al. (1983); Mehendale et al. (1994) showed that chlordecone potentiated carbon tetrachloride induced hepatotoxicity. Our group showed that necrotic cell injury could be reversed by zinc, vitamin $B_{12}$ and glutathione (Rana and Tayal, 1981). Studies of my group were influenced by the contribution of Keppler (1975 ); Recknagel and Ghoshal (1966); Gillette et al. (1974). Mechanisms responsible for necrosis are discussed in second part of this article.

Necroptosis : Regulated necrosis or necroptosis is a complex process. It is not triggered by one signalling cascade but by the activation of several signalling pathways that are provoked by a wide range of stimuli (Duprez et al., 2009). It is a regulated process of cell death that involves ligand binding to TNF (tumor necrosis factor) death domain receptors. Several human pathological conditions including viral infection and neurological disorders viz. Huntington, Parkinson and Alzheimer can cause necroptosis (Vandenabeele et al., 2010). Necroptosis and apoptosis, both are attributed to similar ligand i.e. TNF/TNFa, FASLG/FasL and TNFSF10/TRAIL, typically through the action of RIPK1 and RIPK3 (receptor interacting serine/threonine kinase 1 and 3). RIPK3 is known to activate MLKL mixed lineage kinase domain like pseudokinase) that triggers necroptosis (Vanlangenakker et al. 2008).

Apoptosis : The term apoptosis has been derived from a Greek word meaning "falling off", as the leaves from a tree. It is a synonym to programmed cell death (PCD), a concept proposed by Lockshin (1969). They propounded that cells can commit suicide when required by the organism. It may be an inherent development process or may arise as a response to unknown stimulus. These observations encouraged a search for evidence of gene activation culminating in late 1960s and early 1970s with the recognition that inhibition of protein synthesis can delay or prevent cell death (Lockshin, 1969; Munck, 1971; Martin et al., 1988; Ucker et al., 1989; Openheim et al., 1990). In subsequent years, apoptosis was further classified into intrinsic apoptosis and extrinsic apoptosis.

Intrinsic apoptosis: It is initiated by a variety of microenvironmental disturbances viz. growth factor withdrawl, DNA damage, endoplasmic reticulum stress, overload of reactive oxygen species, replication stress and micro-tubular defects (Czabotar et al., 2014; Ross et al., 2016; Brumatti et al., 2010). Apoptotic cells retain plasma membrane integrity and metabolic activity (Fig. 2). The critical steps of intrinsic apoptosis are mitochondrial outer membrane permeabilization (MOMP) (Tait and Gram, 2010), which is controlled by proapoptotic and antiapoptotic members of BCL-2 protein family. The inhibitors include BCL-2, BCL-XL, MCL-1, and A1. Whereas, promoters of apoptosis are Bax, Bid and BCL-XS. It is the overall prevalence of BCL-2 or Bax in a cell that will ultimately decide whether a cell will die or be rescued. In physiological conditions, $\mathrm{BaX}$ continuously travel between the outer membrane (OMM) and cytosol where it exhibits a quiescent monomeric or inactive dimeric conformation (Edlich et al., 2011; Schellenberg et al., 2013). Intriguingly, BAK resides in the lipid bilayer of OMM. Retro-translocation of BAK from OMM to cytosol has also been reported (Todt et al., 2015). MOMP is antagonized by antiapoptotic members of the BCL2 family. They promote cellular survival by regulating $\mathrm{Ca}^{2+}$ homeostasis in ER ( Rana, 2020), by promoting bioenergetic metabolism (Bonora et al., 2015) and contributing to the redox homeostasis (Rana, 1997). The interaction between antiapoptotic and proapoptotic BCL2 family members are known to have major therapeutic values (Kotschy etal., 2016).

Extrinsic apoptosis : This signalling pathway involves death receptors viz. TNF family. Members of TNF receptor family share cysteine rich extracellular domains and a cytoplasmic death domain containing about 80 amino acids. Death domain transmits death signal from cell surface to intracellular signalling pathways (Aggarwal et al., 2012). Best characterized ligand and corresponding death receptors include FasL/FasR, TNFa/TNFR1, Apo3L/DR3, Apo2L/DR4 and Apo2L/DR5. The binding of Fas ligand to Fas receptor results in the binding of the adapter protein FADD and TRADD. These events lead to the formation of death inducing signalling complex (DISC) (Dickens et al., 2012). DISC activates procaspase 8 . Once caspase 8 is activated, the execution phase of apoptosis is triggered. Caspase 3, caspase 6 and caspase 7 function as executioner caspases. Amongst these, caspase 3 is considered to be most important. Caspase 3 cleaves ICAD to release CAD. CAD degrades chromosomal DNA and causes chromatin condensation.

Autophagy : The term autophagy or autophagocytosis is derved from a Greek word "autophagos" meaning "self devouring". It is a naturally regulated mechanism that removes unnecessary or dysfunctional components of the cell. Belgian biochemist de Duve (1983) from Louvain University coined this term after his discovery of lysosomes. Eventually he was awarded Nobel Prize in Physiology and Medicine in 1974. It is considered as an adaptive process that protects the cell from nutrient starvation and ATP deficiency. It is manifested through the action of a phagophore, which expands and matures to form an autophagosome. The autophagosome may fuse with endosome and ultimately with a lysosome to form an autolysosome.

It can further be classified as macroautophagy; microautophagy; chaperone mediated autophagy and crinophagy. However, macroautophagy is best characterized primary autophagic pathway. It is primarily a nonselective process, whereas microautography is a selective process. Further, selective autophagy may be termed as mitophagy or peroxypahagy. 


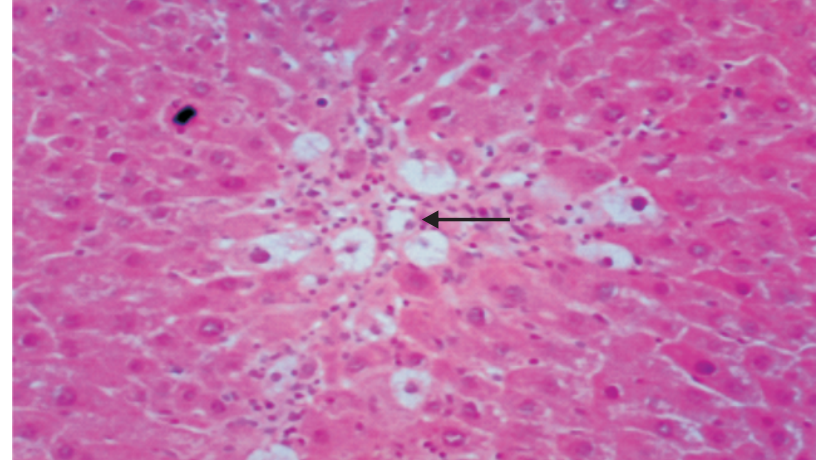

Fig. 1 : Representative cross section of the liver of mice treated with carbon tetrachloride shows necrotic cell death. H/E stain. X100. (source: Toxicology Lab., CCS University, Meerut)

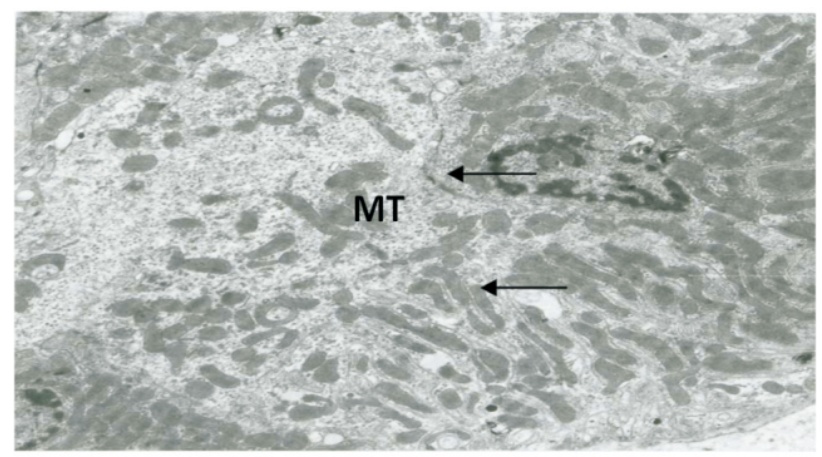

Fig. 3 : Representative electron microphotograph of the liver of rat treated with arsenic exhibits morphological changes in mitochondria (MT) as a denominator of cell injury. X1200. (source: Toxicology Lab., CCS University, Meerut)

It has now been established that in multiple pathological conditions, molecular machinery of autophagy contributes to cell death (Denton et al., 2012; 2015; Anding and Baehrecke, 2015). Autophagy dependent cell death may also contribute in the pathogenesis of human disorders. Autophagy promoting factor (APF) has been implicated in the pathogenesis of myocardial infarction owing to its ability to directly promote the expression of ATG7. Another specific variant of autophagy is autosis that relies on plasma membrane $\mathrm{Na}^{+} / \mathrm{K}^{+}$ATPase. Inhibition of this enzyme confers neuroprotection in rat model of neonatal hypoxiaischemia (Liu et al., 2013).

Ferroptosis : As the name suggests, ferroptosis is caused by disturbances in the intracellular microenvironment notably lipid peroxidation and iron availability. It occurs independently of caspases, necrosome components of cyclophillin D and autophagy (Dixon, 2017; Yang and Stockwell, 2016; Xie et al., 2016). It exhibits morphological changes viz. mitochondrial shrinkage, reduced or disappeared cristae and ruptured outer

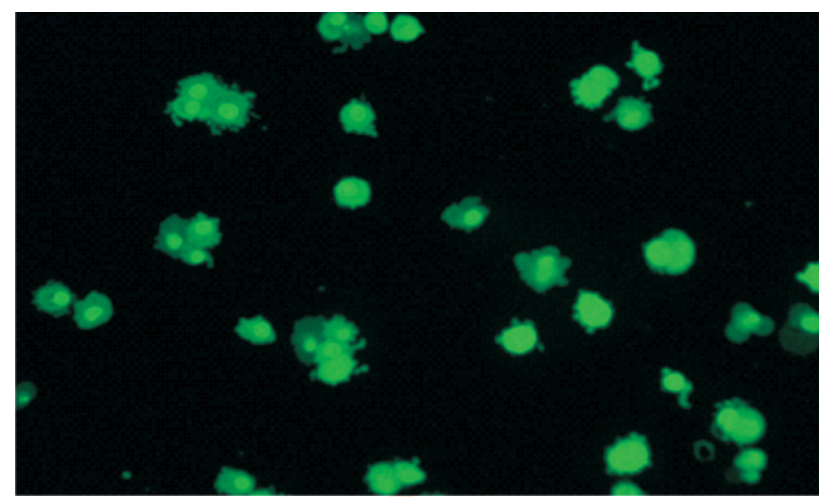

Fig. 2 : Representative MCF7 breast cancer cells treated with nanoarsenic exhibit apoptosis. (source: Toxicology Lab., CCS University, Meerut)

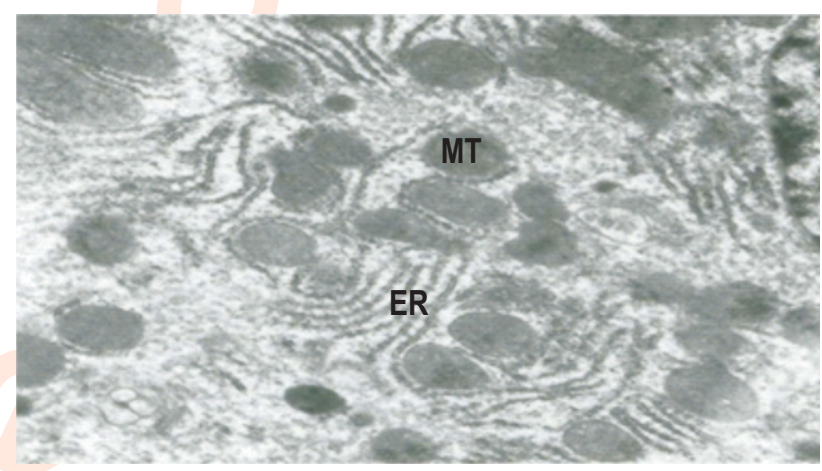

Fig. 4 : Representative electron microphotograph of the liver of rat treated with arsenic shows unfolding of endoplasmic reticulum (ER) as a maker of cell injury.MT=mitochondria. X2000. (Source: Toxicology Lab., CCS University, Meerut)

mitochondrial membrane (Vanden Berghe et al., 2014). Ferroptosis inducing agents i.e. erastin (Yang and Stockwell, 2008) and ferroptosis inhibiting agents like ferrostatins and liproxstatins (Hofmans et al., 2016; Friedmann and Angeli, 2014) are known now. Glutathione peroxidase-4 (GPx4) is also considered as the potent endogenous inhibitor of ferroptosis (Seiler et al., 2008). Peroxidation of polyunstaurated fatty acid (PUFA) seems to be regulated by antagonistic behaviour between lipoxygenases (LOXs) which directly catalyze LPO and GPx4 which directly inhibits LPO. Multiple LOXs are involved in LPO and consequent ferroptosis. This cascade of events can be prevented by a few antioxidants viz. ferrostain-1; liproxstatin- 1 as well as a tocopherol that function as ROS scavengers. The precise role of this type of cell death in development and cellular/organ homeostasis warrants further studies.

Pyroptosis : The term pyroptosis was originally coined by Cookson and Brennan ( 2001) to define a particular type of RCD partially resembling apoptosis but dependent upon caspase 1. It 
is triggered by disturbances in extracellular or intracellular homeostasis related to innate immunity. It exhibits a peculiar form of chromatin condensation that differs from apoptosis (Jorgenson and Miao, 2015). Molecular mechanisms of pyroptosis involve activation of CASP1, CASP3, and CASP5 depending upon the stimulus (Vanden Berghe et al., 2014; Aachoui et al., 2013). Proinflammatory effects of pyroptosis are mediated by IL-1 $\beta$ and IL 18 secretion (Franchi et al., 2009). Further, caspases induce pyroptosis by catalyzing the cleavage of gasdermin proteins (GSDMD). GSDMD lead to the formations of pores in the plasma membrane causing pyroptosis (Kayagaki et al., 2015).

Parthanatos : In Greek, parthanatos literally means "death". It is a form of PCD which is different from necrosis and apoptosis. It is caused by the hyperactivation of a specific component of the DNA damage response (DDR) machinery called, poly (ADP-ribose) polymerase 1 (PARP1). Not only DNA damage but other factors viz. hypoxia, oxidative stress, hypoglycaemia and inflammation may cause parthanatos (David et al., 2009; Fatokun et al., 2014). Reactive nitrogen species (RNS) including NO induce PARP1 hyperactivation that manifests cytotoxic effects namely, $\mathrm{NAD}^{+}$and ATP depletion; accumulation of poly(ADP-ribose) polymers and poly (ADP-ribosyl) ated proteins at mitochondria ultimately causing changes in voltage dependent channels in MOMP (Yu et al., 2002; Andrabi et al., 2006). Key machanism involved in parthanatos is the binding of poly(ADP-ribose) polymers to apoptosis inducing factor (AIF). Release of AIF into cytosol and its translocation into nucleus mediates DNA fragmentation and chromatin condensation (Fatokun et al., 2014). Parthanatotic DNA fragmentation occurs independently of apoptotic caspases and endonuclease G. Specific pharmacological inhibitors of PARP1are known to delay parthanatos in multiple cell types (Curtin etal., 2013).

Parthanatos is known to contribute in many pathological conditions viz. some cardiovascular and renal disorders, diabetes, cerebral ischemia and neurodegeneration (Eliasson et al., 1997; Kim and Padamilam, 2011).

Entosis : Entotic cell death is a synonym of cell cannibalism. It occurs in both healthy and malignant human tissues. It is manifested by non phagocytic cells of the same (homotypic) or a different (heterotypic) cell type (Krishna et al., 2016; Florey et al., 2015). Internalization of cells is followed by their death. These cells are known as entotic cells. Several mechanisms have been proposed to explain entosis viz. deregulation of myosins during cell to cell contact and /or variations in mechanical properties of proliferating cells (Wan et al., 2012; Sun et al., 2014). Internalization of entotic cells occurs through cell invasion rather than by phagocytosis (Krishna et al., 2016). Integrin dependent junctions are formed between entotic and engulfing cells. Cell adhesion proteins i.e. cadherin 1 (CDH1) and catenin a 1 are also involved in this process (Overholtzer et al., 2007). Engulfed entotic cells are removed by a RCD process that occurs independently of BCL2 proteins and caspases. However, an autophagy related mechanism, LC3 -associated process is employed for their elimination (Kim and Overholtzer, 2013). Entosis has been reported in several human neoplasms plausibly serving as an oncosuppressor mechanism (Krishna et al., 2016).

NETotic cell death : Nomenclature Committee on cell death defines NETotic cell death as a ROS dependent modality of RCD restricted to cells of hemato-poietic origin and associated with NET (neutrophil extracellular trap) extrusion. NETs are produced in response to various microbial and sterile activators. Nucleic acids contained in NETs are of mitochondrial rather than nuclear origin (Yousefi et al., 2009; Lood et al., 2016). NETotic cell death is caused by a signalling pathway that involves Raf-1, protooncogene, serine-threonine kinase, mitogen activated protein kinases (MAP2Ks) and ERK2, culminating with NADPH oxidase activation and consequent ROS generation (Remijsen et al. (2011).

Lysosome dependent cell death : Lysosome dependent cell death has been studied under several pathological conditions including inflammation, ageing, neurodegeneration, cardiovascular disorders and drug/xenobiotic response (Aits and Jattela, 2013; Serrano-Puebla and Boya, 2016). It is initiated by lysosomal membrane permeabilization (LMP) resulting in the release of lysosomal contents into the cytoplasm. It has been hypothesized that ROS play a prominent role in LMP (Kurz et al., 2008). ROS were found to activate $\mathrm{Ca}^{2+}$ channels (SumozaToledo and Penner, 2011). Cytosolic cathepsins induce RCD by catalyzing activation or inactivation of a few substrates viz. BID, $B A X$, anti-apoptotic BCL2 family and XIAP. Thus a lethal cascade for RCD is generated involving MOMP and caspases (DrogaMazovec et al. 2008).

Cellular senescence : Cellular senescence was first discovered by Hayflick and Moorhead (1961). It refers to a pathological process in which the cells permanently lose their proliferative capacity while remaining viable and metabolically active (Campisi, 2013). Morphologically, they exhibit flattening, intracellular vacuolization, cellular/nuclear enlargement and altered chromatin structure. Biochemical changes in these cells include increased activity of lysosomal galactosidase B 1; inhibition of cyclin dependent kinases (CDKs); and consequent dephosphorylation of various retinoblastoma protein family. Other proliferation markers are wanting in these cells. Senescent cells secrete different types of cytokines and chemokines, growth and MMPs (He and Sharpless, 2017).

Senescence is known to contribute in embryogenesis and pathophysiological processes viz. tissue repair and regeneration, immunity, preservation of the stem cell compartment and onco-suppression (Baar et al., 2017). Post mitotic senescence has also been linked to mammalian ageing (Zglinicki et al., 2021). 
Mechanisms of cell death : Historically, toxicological investigations in seventies relied upon histo-pathological and biochemical endpoints in animals to draw conclusions on the effects of drugs/chemicals in target organ systems. It was in 1971 that the concept of marriage between histochemistry and toxicology was visualized by us. Reasons of cell death i.e. hypoxia, dys-enzymia, fatty infiltration and fibrosis were addressed in our earlier publications (Rana and Agrawal, 1971; Rana, 1974; 1977). Science of toxicology started dominating other disciplines of bio and medical sciences. How does a cell become injured and subsequently die or recover after exposure to a poison was the focal theme of many laboratories. Two benchmark books, "Biochemical Mechanisms of Liver Injury" (Slater, 1978) and "Biochemical Toxicology of Environmental Agents" (de Bruin, 1980) changed the landscape of experimental research in toxicology over the globe. Different schools in U.S.A. (Smuckler group); Canada (Plaa); U.K. (Orlandi); Italy (Dianzani) were engaged in delineating the mechanism of liver cell necrosis. Our research group also dedicated those years to reveal mechanisms of cell death induced by a few cytotoxic chemicals. Fascinations evolved during this journey are summarized in following paragraphs. First section of this article described different types of cell death. Present section highlights the evolution of mechanisms of cell death with inputs of from our own contributions made during last fifty years.

Molecular mechanisms of cell death are manifested by novel signalling pathways that orchestrate cell death. These common mechanisms of regulated as well as accidental cell death include phase I and phase II metabolism; oxidative/ peroxidative stress; reductive stress; endoplasmic reticulum stress and mitochondrial stress. I shall make an attempt to justify this statement with following examples.

Role of Cytochrome $P_{450}$ : Detoxication of xenobiotics has been and still is a subject of prime concern in biochemical toxicology. The parent compound is metabolically converted into a more polar form by phase -I enzymes. Amongst these, the family of $\mathrm{CYP}_{450}$ enzymes that are found in some prokaryotes and all eukaryotes play a paramount role in oxidative, reductive and peroxidative biotransformation of many endogenous and exogenous compounds. A German biochemist Klingenberg (1958) discovered a carbon monoxide binding pigment (later termed CYP) in liver microsomes while working at Johnson Foundation in Philadelphia. A few years later Estabrook et al. (1963) demonstrated its role as a terminal oxidase in steroid hydroxylation catalyzed by adrenal cortex microsomes. Axelrod et al. (1963) at NIH showed that liver microsomes could catalyze the NADPH linked oxidative metabolism of various drugs. True beginning was made by two Japanese Scientists Omura and Sato (1964) from Osaka University who established the hemoprotein nature of $\mathrm{CYP}_{450^{\circ}}$. The role of $\mathrm{CYP}_{450}$ in drug metabolism was further supported by the experiments with phenobarbital and methylcholanthrene that induced $\mathrm{CYP}_{450}$ in liver microsomes and enhanced rates of oxidative drug metabolism (Orrenius, 1965). Host of examples are known today where $\mathrm{CYP}_{450}$ bioactivates harmless and nonreactive substrates into reactive and potentially harmful metabolites. More than 400 genes for CYP have been identified till date. Human genome contains 115 genes, of which 57 are functional and the remaining are treated as pseudogenes. The enzyme is predominantly found in liver but also in skin, intestine and lungs. Several benchmark discoveries on the role of $\mathrm{CYP}_{450}$ in cell death have been made. Guengerich (2001) pioneered the studies describing $\mathrm{CYP}_{450}$ dependent reactions involved in chemical toxicity.

In most of our experiments, $\mathrm{CYP}_{450}$ was estimated as an essential observation. It was interesting to demonstrate the influence of several factors viz. gender (Verma and Rana, 2004) and circadian rhythms (Rana et al., 2007) on CYP ${ }_{450}$ activity in benzene treated rats. A book entitled, "Fifty years of Cytochrome P450 Research" (Yamazaki, 2014). CYP ${ }_{450}$ research has been now expanded into many disciplines viz. medicine, agriculture, biotechnology and drug development. It has been established now that $\mathrm{CYP}_{450}$ are involved in the production of reactive oxygen species (Shimamoto, 2013). Significance of reactive oxygen species (ROS) is fundamental to our understanding on cell death.

Reactive oxygen species and cell death : Reactive oxygen species (ROS) namely, the superoxide anion, hydrogen peroxide, singlet oxygen, nitric oxide, hydroxyl radicals are the products of normal aerobic metabolism. Biochemical processes like oxidation/peroxidation, inflammation, phagocytosis, exposure to ultraviolet radiation and xenobiotics lead to generation of ROS. Fenton or Haber Weiss reactions too, contribute to increased formation of ROS. They can cause oxidative DNA damage, protein oxidation and lipid peroxidation (LPO). LPO, today is central to our understanding on cell injury. It is by and large accepted that membrane damage by xenobiotics is the gateway for the entry of xenobiotics in the cell. Landmark paper from Recknagel and Ghoshal (1966) attributed cell injury to peroxidative damage of polyunsaturated fatty acids (PUFA) caused by xenobiotics. Subsequent papers from his group unfolded the mystery of carbon tetrachloride induced liver inury (Recknagel, 1967; Recknagel et al., 1982). Tappel (1973) defined this phenomenon as oxidative deterioration of PUFA. Free radical mediated peroxidation of PUFA can take place through different mechanisms. This mechanism of cell injury was considered central to the pathogenesis of disease (Farber, 1982). The role of free radicals in biology and medicine was very precisely discussed by Halliwell and Gutteridge (1985) in a popular book, "Free Radicals in Biology and Medicine". This book revolutionized the concept of cell death.

Lipid peroxidation and consequent events induced by heavy metals and organic solvents mainly in the liver and kidney 
of rat were extensively studied by our group (Rana and Kumar,1987; Rana and Boora, 1992; Rana et al., 1995; Rana et al., 1997; Rana and Rastogi 1991; Rana and Chauhan 1998; Rana and Gupta, 2000; Rana and Kumar, 2000). These investigations have significantly helped in elucidating the mechanisms of their toxicity. It has been established now that excessive generation of ROS results into oxidative damage to other cellular macromolecules.

Oxidative stress and cell death: Oxidative stress or more precisely oxido-reductive stress can be defined as, "disturbances in the pro-oxidant and antioxidant balance of the cell." In healthy organism, several biochemical reactions generate pro-oxidants in the form of oxygen derived free radicals, excited states etc. These radicals/ ROS to a great deal, are neutralized by antioxidant defence mechanisms evolved in the cell. However, under adverse conditions this delicately maintained balance is shifted to pro-oxidants due to enhanced oxidative stress. The central to all studies on oxidative stress is a wonder molecule, a tripeptide called glutathione. The discovery of this molecule was perhaps the most important event in toxicology. Kosower and Kosower (1969) coined a phrase in its honour, "Lest I forget thee glutathione." Extensive studies on glutathione led Arias and Jakoby (1976) to write a book, "Glutathione, metabolism and function". It was soon followed by two German scientists- Sies and Wendel (1978) who wrote, "Functions of glutathione in liver and kidney". Jakoby (1980) wrote a wonderful book, "Enzymatic basis of detoxication". These publications inspired various research groups including me and most of our investigations from 1980 s till date also focussed on the role of oxido-reductive stress in the toxicity of different environmental xenobiotics.

I got the opportunity to learn about "glutathione cycle" in hepatic parenchymal cell, while working in the laboratory of Professor Masana Ogata, Department of Public Health., Okayama University Medical School, Japan in 1989 as a senior JSPS scientist. Depletion in GSH was considered as a reliable molecular marker of oxidative stress. In due course of time, we could study oxidative stress, mainly in liver and kidney of rats treated with organic solvents, heavy metals and recently with nanoparticles ( Rana and Rastogi, 1991; Rana and Boora, 1992; Rana and Rastogi, 1993; Rana and Kumar, 1995; Rana et al., 1995; Rana et al., 1997; Rana and Verma, 1997; Rana et al., 2002; Rana and Verma, 2004 and Rana et al., 2018). All these reports confirmed that oxidative stress was the major cause of cell death manifested by the selected xenobiotics. Moreover, GSH offered a protective mechanism against the accumulation of reactive and electrophilic drug metabolites. Several authors revealed the importance of GSH conjugation in cell defence. This information was meticulously reviewed by Orrenius (2019) from Karolinska Institute, Sweden.
Importance of antioxidants in cell death : It has been established now that persistent exposure to pro-oxidants manifests into oxidative damage to proteins, lipids and DNA. These mechanisms contribute to the etiology of several diseases viz. atherosclerosis, rheumatoid arthritis and degenerative processes associated with ageing. Aerobic organisms possess potent physiological defences to neutralize and minimize the potentially cytotoxic effects of reactive oxidants. Broadly, these systems have been classified as non enzymatic and enzymatic antioxidants. Last three decades witnessed immense interest of scientists in the therapeutic significance of these enzymes. High rated journals viz. Redox Reports and Antioxidants and Redox Signalling were started to manage the publication of increasing number of papers. The importance of antioxidant enzymes viz. superoxide dismutase (SOD), glutathione peroxidase (GPx) and catalase (cat) against oxidative stress has been studied in a number of laboratories.

Enzymatic antioxidants : Superoxide dismutase (SOD) is an enzyme that alternately catalyzes the dismutation (partitioning) of superoxide radical $\left(\mathrm{O}_{2}^{-}\right)$into ordinary molecular oxygen $\left(\mathrm{O}_{2}\right)$ and hydrogen peroxide $\left(\mathrm{H}_{2} \mathrm{O}_{2}\right)$. It was discovered by McCord and Fridovich (1969). There are three major families of SOD depending upon its protein fold and metal cofactor (Cu/Zn SOD; MnSOD and NiSOD). Excellent reviews on the role of SOD in cell death are also available in literature. Miao and Clair (2009) reviewed its implications in disease.

Another important enzyme that catalyzes the reduction of hydrogen peroxide and organic hydroperoxides is a selenium dependent glutathione peroxidase (Gpx). It was detected in plants and animals in $19^{\text {th }}$ century by Schonbein (1863) and named "peroxidase" by Linossier (1898). It was first selenoprotein to be detected by Flohe et al. (1973) and Rotruck et al. (1973). In humans seven isoforms of this enzyme are known. Five of these are selenoenzymes and two contain cysteine instead of selenium. A number of reports from our laboratory have elucidated the protective role of GPx against the toxicity of organic solvents and toxic elements (Rana and Boora, 1992; Rana and Rastogi, 1993; Rana and Kumar, 1995;Rana and Singh, 1996; Rana and Rastogi, 2000; Allen and Rana, 2004). Role of selenoproteins in human health has been comprehensively reviewed by Papp et al. (2007).

Catalase is a heme protein that decomposes $\mathrm{H}_{2} \mathrm{O}_{2}$ to $\mathrm{O}_{2}$ and $\mathrm{H}_{2} \mathrm{O}$. It is a peroxisomal enzyme (Reddy et al., 1995 ). Its deficiency in human population is known as acatalesemia. Extensive studies on drug metabolism/ toxicity in acatalesemic human subjects and mice were performed by Ogata (1991) at Okayama University, Japan. He discussed the role of catalase in a review article "Acatalesemia" that appeared in Human Genetics. Perspectives of mammalian acatalesemia and genetic toxicology were reviewed again by Ogata et al. (2008). 
Another group of antioxidant enzymes include glutathione reductase, glucose 6-phosphate dehydrogenase. They are substrate specific and play significant role in cell death.

Non-enzymic antioxidants: Although there are several nonenzymic antioxidants ( $\alpha$ tocopherol, ubiquinol-10, $\beta$-carotene, bilirubin, ascorbate, glutathione, urate and plasma proteins), best studied amongst these include a- tocopherol, ascorbic acid, glutathione, metallothionein and a hormone melatonin. Vitamin $\mathrm{E}$ is a chain breaking antioxidant in biological membranes (Niki , 1988). It reacts with $\mathrm{OH}$ or most commonly with lipid peroxyl radicals (LOO) to form a long live a tocopheryl radical. This hypothesis was proved by our experiments made in cadmium and copper fed rats (Rana et al., 1997; Rana and Verma, 1997). Asorbate was found to be protective against arsenic toxicity (Singh and Rana, 2010; Sohini and Rana, 2007).

Now, I would like to introduce the readers of this article to a wonder antioxidant molecule- the metallothionein (MT). This low molecular weight $(6.5 \mathrm{kD})$ protein was discovered by Marghose and Vallee (1957) in horse kidney. 30\% amino acid residues of MT are cysteines. Therefore, protein has a large number of $\mathrm{SH}$ groups that can be coordinated by metal ions. One molecule of MT can bind seven atoms of $\mathrm{Cd}$. I remember classic work done on MT by Cherian (1994) and Klaassen et al. (1999). Protective role of MT against metal toxicity has been studied by our laboratoriy also (Singh and Rana, 2002). However, Rana and Kumar, $(2000,2001)$ confirmed their anti-carcinogenic potential . Recently, protection offered by nanoparticles of zinc against dimethylnitrosamine induced hepatocelluar death was also attributed to MT (Rani et al., 2018).

For many of us, it might be quite surprising to know that a hormone may also play an antioxidative role. Melatonin ( $\mathrm{N}$-acetyl5-methoxytryptamine) is secreted by pineal gland. It functions as a time giver (zeitgeber) in the regulation of circadian rhythms (Arendt, 2003). It synchronizes reproductive cycle in photoperiodic species (Reiter, 1980). An antioxidative protection by melatonin against oxidative injury induced by acetaminophen (Thomas -Zapico and Coto-Mentes, 2005), carbontetrachloride (Ogeturk et al., 2004) and benzene (Sharma and Rana, 2010, 2013) has also been reported. Protection offered by melatonin against toxicity induced by several toxic elements was recently reviewed by Rana (2018). Pleiotropic functions of melatonin make it an inevitable molecule.

Role of calcium in cell death : We know that calcium is an essential element. It governs a host of vital cell functions and hence is necessary for cell survival. Intriguingly, it has also been established that cellular $\mathrm{Ca}^{2+}$ overload may contribute in cell death. Fleckenstein et al. (1974) for the first time observed that entry of excess $\mathrm{Ca}^{2+}$ into cardiomyocytes might lead to cardiac pathology and ischemia. Subsequently it was found that receptor overstimulation (Leonard and Salpeter, 1979) or exposure to toxic agents (Trump and Berezesky,1995) may cause lethal $\mathrm{Ca}^{2+}$ influx into cells. Certain xenobiotics can interfere with $\mathrm{Ca2}^{+}$ sequestering mechanisms. A nonspecific increase in the permeability of plasma membrane may lead to a rapid influx of $\mathrm{Ca}^{2+}$ ions. Contrarily, xenobiotics can modify the calcium pump of the plasma membrane or ER either by oxidative damage or by covalent binding to these structures. Consequences of xenobiotic induced upsurge in $\mathrm{Ca}^{2+}$ are manifold. Moderate increases in calcium lead to activation of caspase and apoptosis (Wyllie, 1980). Major effects of increased $\mathrm{Ca}^{2+}$ are activation of calpains, endonucleases and calcium dependent phospholipases, in particular phospholpiase A2 that lead to necrotic cell death. Rana and Rastogi (1991) showed that parathyroidectomy offered protection against carbon tetrachloride induced hepatotoxicity through inhibition of phospholipase A2. A number of papers on role of $\mathrm{Ca}^{2+}$ in apoptosis has been published (Orrenius et al., 2003; Orrenius and Zhivotovsky, 2006; Orrenius et al., 2007; Orrenius et al., 2011 and Orrenius, 2019). The link between apoptosis and $\mathrm{Ca}^{2+}$ during heavy metal toxicity was reviewed by Rana (2008). More recently, ER stress induced by heavy metals has also been linked to calcium dependent processes (Rana, 2020).

Cell death and redox cycle : Reductive stress (RS) is the counterpart of oxidative stress (OS). It can occur as a response to conditions that shift the redox balance of important biological redox couples, viz. NAD $/ \mathrm{NADH}, \mathrm{NADP}^{+} / \mathrm{NADPH}$, and GSH/GSSG to a more reducing state. Several mechanisms are known to explain reductive stress. It may occur due to over expression of antioxidant enzymes that lead to excess of reducing equivalents that can deplete ROS, driving the cells to RS. Redox steady states are fundamental to health and disease. It has been established now that cell metabolism is governed by a redox code (Jones and Sies, 2015). The redox code is a critical complement of the genetic code, the epigenetic code and the histone code in the molecular logic of life (Oronsky et al., 2014). Redox code is manifested by redox switches and redox active metabolites such as $\mathrm{H}_{2} \mathrm{O}_{2}$, nitric oxide or hydrogen sufide. These molecules are now known to play a pivotal role in cellular death. Impressive research on these molecules have been performed by Prof Helmut Sies from University of Dusseldorf, Germany ( Sies and Summer, 1975; Sies, 1986; Sies and Jones, 2007), Prof Hideo Kimura from Sanyo Onoda City University, Yamaguch, Japan ( Kimura 2013, 2015) and a Nobel awardee Prof Gregg L Semenza from Johns Hopkin University School of Medicine (Semenza, 2005, 2007). Semenza shared Noble Prize in Physiology and Medicine in 2019. The outcome of present researches on Redox Biology is expected to open new avenues in Redox Medicine.

Mitochondrial stress and cell death : A variety of chemicals/ drugs/ xenobiotics can disturb mitochondrial (mT) function by inducing stress through mechanisms of electron transfer, 
inhibition of energy transfer and uncoupling of ATP synthase. ROS target mT DNA of human genome which encodes thirteen polypeptides, twenty two transfer RNAs (tRNAs) and two ribosomal RNAs (rRNAs) all of which are essential for electron transport and ATP generation by oxidative phosphorylation (Anderson et al., 1981). Several chemicals can cause mutations in mTDNA (Valente et al., 2016). In turn, these mutations increase the sensitivity of mT to stress (Chan, 2017; Luz et al., 2017). Stress can change the morphology and function of $\mathrm{mT}$ through fusion and fission (Meyer et al., 2017). Fig 3 exhibits these morphological changes. Role of reactive oxygen species in $\mathrm{mT}$ mediated cell death was reviewed by Orrenius (2007). For further information, readers are advised to consult reviews written by Meyer et al., (2013); Meyer and Chan, (2017); Dykens and Will (2007).

Endoplasmic reticulum (ER) stress and cell death : Several drugs/chemicals are now known to induce ER stress. It could lead to deleterious effects within cells and tissues including accumulation of lipids, cytolysis, inflammation, energy depletion, redox imbalance and cell death (Malhi and Kaufman, 2011; Coop et al., 2012; Cheng et al., 2013; Chen et al., 2014). Since many xenobiotics are reactive, their influence on structure and function of ER is inevitable. ER stress is expressed by accumulation of unfolded or misfolded proteins in the luman of ER (Byrd and Brewer, 2012). ER stress is known to contribute in the pathogenesis of several diseases viz. diabetes, neurodegenerative disorders, inflammatory and autoimmune diseases (Hetz etal., 2013; Wang and Kaufman, 2012).

A mechanism that modulates ER function is known as unfolded protein response (UPR). ER stress and generation of ROS are fundamental to UPR signalling. ROS can trigger UPR by themselves (Santos et al., 2009). ER stress plays an important role in the toxicity of heavy metals (Rana, 2020). ER maintains a close contact with mitochondria (Fig 4). This contact facilitates regulated transfer of calcium between the two organelles. It is assumed that too much or too little cross talk between two might contribute to metabolic dysfunction (Patergnani et al., 2011).

Global gene expression profiling : Toxicology underwent a major technological transformation in its ability to generate global gene expression profiling data on a massive scale. High throughput techniques viz. toxicogenomics, proteomics and metabolonomics ushered a new era in molecular toxicology (Hamadeh and Afshar, 2004). Genes and proteins responsible for cell death caused by a variety of xenobiotics have now been identified (Jeong et al., 2006; Lim et al., 2007; Park et al., 2008; Heo et al., 2010). Molecular markers of cell death are being identified. Two reviews on these efforts were written by me along with colleagues of Korea Institute of Toxicology, Daejeon (South Korea) where I worked in 2006 as a fellow of Korean Education Foundation (Yoon et al., 2007; Yoon et al., 2008). The concept of "Molecular markers in Health and Disease", was the focus of a plenary lecture delivered by me during International Conference of Toxicogenomics and Proteomics," held at Incheon, South Korea from 1-2 November 2007 (Rana et al., 2007). Tox-21 (Toxicity Testing in 21st Century), initiative taken by NRC and it collaborators aims to advance the molecular understanding and predictability of toxic responses that would help in safeguarding human health from a variety of poisons.

Cross talk amongst different mechanisms of cell death: Above account signifies that multiple signal transduction cascades are responsible for RCD of a variety of cell types. Majority of drugs/chemicals/xenobiotics are capable of producing ROS. In addition they induce oxido-reductive stress, mitochondrial stress and ER stress. The cross talk amongst these mechanisms has recently been debated in a few reports. The interorganelle cross talk apparently involves several "molecular switches" within the signalling network. Furthermore, nature and severity of the stimulus, cell type and hierarchy of interorganelle cross talk might result in different cell death modalities. For example, depletion of energy metabolism may change the mode of cell death from apoptosis to necrosis. Similarly, inhibition of caspase enzyme might change apoptosis to necrosis or autophagy (Yousefi et al., 2006; Orrenius et al., 2011). ER stress can also cause apoptosis as well as autophagic cell death (Orrenius et al., 2003). Intracellular accumulation of calcium can trigger necrotic cell death but surviving cells may subsequently succumb to apoptosis. Taken together, it is important to delineate a specific mechanism involved in the toxicity of a specific xenobiotic. Intriguingly, all these mechanisms are interdependent and work as closely knitted network of signalling pathways as seen in necroptosis. In a few instances, cell death mechanisms share common signals.

\section{Acknowledgment}

The author is grateful to all those funding agencies that supported my work over the years, in particular the University Grants Commission; Indian Council of Medical Research; Council of Scientific and Industrial Research and Department of Science and Technology. I am thankful to many colleagues, research students and post docs who made significant contribution to the studies discussed in this article. I would like to acknowledge the inspiration and advice of mentors, (late) Prof VP Agrawal, Prof R.C. Dalela, Prof Masana Ogata and Prof K Taketa. Warm friendship of Prof. Zoltan Gregus (Hungary), Dr C.W.Song and $\mathrm{Dr} S \mathrm{~J}$ Yoon (South Korea) is gratefully acknowledged. Finally, I express my sincere thanks to my wife, Usha who supported me during all these years and looked after our children and grand children.

Conflict of interest : The author is not aware of any conflict of interest that may affect the objective of this article.

Author note : Two scientists quoted in this article i.e. Prof 
Christian de Duve and Prof Gregg L Semenza were awarded Nobel Prize. I had the opportunity of meeting Prof $C$ de Duve at Kyoto (Japan) in 1972 during International Congress of Histochemistry and Cytochemistry. I met Prof Gabriel Plaa at Montreal in 2007 during International Congress of Toxicology. We had long discussions on the role of LPO in cell injury. I was fortunate to meet Prof Stein Orrenius at Salt Lake City (USA) in 2010 during SOT meeting where we discussed the role on intracellular calcium and mitochondria in cell death.

\section{References}

Aachoui, Y., V. Sagulenko, E.A. Miao and K.J. Stacey: Inflammasomemediated pyroptotic and apoptotic cell death, and defense against infection. Curr. Opin. Microbiol., 16, 319-326 (2013).

Aggrawal, B.B., S.C. Gupta and J.H. Kim: Historical perspectives on tumor necrosis factor and its superfamily: 25 years later, a golden journey. Blood., 119, 651-665(2012).

Aits, S. and M. Jaattela: Lysosomal cell death at a glance. J. Cell Sci., 126, 1905-1912 (2013)

Allen, T. and S.V.S. Rana: Effect of arsenic (III) on glutathione dependent enzymes in liver and kidney of fresh water fish, Channa punctatus. Biol.Trace. Elem. Res., 100, 39-48(2004).

Anderson, S., A.T. Bankier, B.G. Barrel, M.H.L. de Bruijn, A.R. Coulson, J. Drouin, I.C. Eperon, D.P. Nierlich, B.A. Roe, F. Sanger, P.H. Schreier, A.J.H. Smith, R. Staden and I.G. Young: Sequence and organization of the human mitochondrial genome. Nature., 290, 457-465 (1981).

Anding, A.L. and E.H. Baehrecke: Autophagy in cell life and cell death. Curr. Top. Dev. Biol., 114, 67-91 (2015).

Andrabi, S.A., N.S. Kim, S.W. Yu, H. Wang, D.W. Koh, M. Sasaki, J.A. Klaus, T. Otsuka, Z. Zhang, R.C. Koehler, P.D. Hurn, G.G. Poirier, V.L. Dawson and T.M. Dawson: Poly (ADP-ribose) (PAR) polymer is a death signal. Proc NatAcad Sci. USA., 103, 18308-13 (2006).

Arendt, J.: Importance and relevance of melatonin in human biological rhythms. Neuroendocrinol., 15, 427-431 (2003).

Arias, I.M., W.B. Jakoby, H. Popper, D. Schachter and D.A. Shafritzs (eds): The Liver Biology and Pathology. Raven Press, New York. (1988).

Arias, I.M. and W.B. Jakoby (eds): Glutathione metabolism and function. Raven Press, New York (1976).

Axelrod, J.: The discovery of the microsomal drug metabolizing enzymes. Trends Pharmacol Sci., 3, 383-386(1963).

Baar, M.P., R.M.C. Brandt, D.A. Putavet, J.D.D. Klein, K.W.J. Derks, B.R.M. Bourgeois, S. Stryeck, Y. Rijksen, H.V. Willigenburg, D.A. Feijtel, I.V. der Pluijm, J. Essers, W.A. van Cappellen, W.F. van IJcken, A.B. Houtsmuller, J. Pothof, R.W.F. de Bruin, T. Madl, J.H.J. Hoeijmakers, J. Campisi and P.L.J. de Keizer: Targeted apoptosis of senescent cells restores tissue homeostasis in response to chemotoxicity and ageing. Cell., 169, 132-147 e116 (2017).

Bonora, M., M.R. Wieckowski, C. Chinopoulos, O. Kepp, G. Kroemer, L. Galluzzi and P. Pinton: Molecular mechanisms of cell death: Central application of ATP synthase in mitochondrial permeability transition. Oncogene, 34, 1475-1486 (2015).

Brumatti, G., M. Salmanidis and G. Ekert: Crossing paths: Interactions between the cell death machinary and growth factor survival signals. Cell Mol Life Sci., 67, 1619-1630 (2010).
Byrd, A.E. and J.W. Brewer: Intricately regulated: A cellular tool box for fine tuning XBP1 expression and activity. Cell., 1, 738-753 (2012).

Chan, S.S.L.: Inherited mitochondrial genomic instability and chemical exposures. Toxicology., 391, 75-83(2017).

Chang, B., H. Gong, H. Xiao, R.B. Peterson, L. Zheng and Kun Huang: Inhibiting toxic aggregation of amyloidogenic proteins, a therapeutic strategy for protein misfolding diseases. Biochim Biophys Acta., 1830, 4860-4871 (2013).

Chen, S., W.B. Jr. Melchoir and L. Guo: Endoplasmic reticulum stress in drug and environmental toxicant induced liver toxicity. J. Env. Sci. Hith. C. Environ. Carcinogen Ecotoxicol. Rev., 32, 83-104(2014).

Cherian, M.G.: The significance of nuclear and cytoplasmic localization of metallothionein in human liver and tumor cells. Environ. Hith. Perspect., 102, 131-135(1994).

Compisi, J.: Ageing, cellular senescence and cancer. Annu. Rev. Physiol., 75, 685-705(2013).

Conrad, M., J.P.F. Angeli, P. Vandenabeele and B.R. Stockwell: Regulated necrosis: Disease relevance and therapeutic opportunities. Nat. Rev. Drug. Discover., 15, 348- 366 (2016).

Cookson, B.T. and M.A. Brennan: Pro-inflammatory programmed cell death. Trends Microbiol., 9, 113-114 (2001).

Coop, M., F. Foufelle and A. Velloso: Endoplasmic reticulum stress, obesity and diabetes. Trends Mol. Med., 18, 59-68 (2012).

Cornillon, S., R.A. Olie and P Golstein: An insertional mutagenesis approach to Dictyostelium cell death. Cell Death Differ., 5, 416-425 (1998).

Curtin, N.J.: Therapeutic applications of PARP inhibitors: Anticancer therapy and beyond. Mol. Aspects Med., 34, 1217-1256 (2013).

Czabotar, P.E., G. Lessene, A. Strasser and J.M. Adams: Control of apoptosis by the BCL2 protein family: applications for physiology and therapy. Nat. Rev. Mol. Cell Biol., 15, 49-63 (2014).

David, K.K., S.A. Andrabi, M. Dawson and V.L. Dawson: Parthantos, a messenger of death. Front Biosci. (Landmark Ed.), 14, 1116-1128 (2009).

de Bruin, A.: Biochemical Toxicology of Environmental Agents. Elsevier Biomedical Press, Amsterdam. (1980)

deDuve, C.: Lysosomes revisited. Eur. J. Biochem., 137, 391-397 (1983).

Denton, D., T. Xu and S. Kumar: Autophagy as a pro death pathway. Immunol Cell Biol., 93, 35-42 (2015).

Denton, D., S. Nikolson and S. Kumar: Cell death by autophagy: facts and apparent artefacts. Cell Death Differ., 19, 87-95 (2012).

Dianzani, M.U., G. Ugazio and L.M. Sena: Recent Advances in Biochemical Pathology and Toxic Liver Injury. Minerva Medica (1975).

Dickens, L.S., I.R. Powley, M.A. Hughes and M. MacFarlane: The complexities of life and death: Death receptor signalling platforms. Exp Cell Res., 318, 1269-1277 (2012).

Dixon, S.J.: Ferroptosis: Bug or feature? Immunol Rev., 277, 150-157 (2017).

Droga-Mazovec, G., L. Bojic, A. Petelin, S. Ivanova, R. Romih, U. Repnik, G.S. Salvesen, V. Stoka, V. Turk and B. Turk: Cysteine cathepsins trigger caspase dependent cell death through cleavage of Bid and antiapoptotic Bcl-2 homologues. J. Biol Chem., 283, 19140-50 (2008).

Duprez, L., E. Wirawan, T.V. Berghe and P. Vandenabeele: Major cell death pathways at a glance. Microbes Infection., 11, 1050-1062 (2009).

Dykens, J.A. and Y. Will: The significance of mitochondrial toxicity in drug 
development. Drug Discov Today., 12,777-785 (2007).

Eastabrook, R.W., D.Y. Cooper and O. Rosenthal: The light reversible carbon monoxide inhibition of the steroid $\mathrm{C} 21$ hydroxylase system of the adrenal cortex. Biochem. Z., 338, 741-755 (1963).

Edlich, F., S. Banerjee, M. Suzuki, M.M. Cleland, D. Arnoult, C. Wang, A. Neutzner, N. Tjandra and R.J. Youle: BCL-x(L) retrotranslocates Bax from mitochondria into the cytosol. Cell., 145, 104-116 (2011).

Eisenberg, T., S. Buttner, G. Kroemer and F. Madeo: The mitochondrial pathway in yeast apoptosis. Apoptosis., 12, 1011-1023 (2007).

Eliasson, M.J., K. Sampei, A.S. Mandir, P.D. Hurn, R.J. Traystman, J. Bao, A. Pieper, Z.Q. Wang, T.M. Dawson, S.H. Snyder and V.L. Dawson: Poly (ADP-ribose) polymerase gene disruption renders mice resistant to cerebral ischemia. Nat Med., 3, 1089-1095 (1997).

Farber, J.L.: Biology of disease. Membrane injury and calcium homeostasis in the pathogenesis of coagulative necrosis. Lab Invest., 47, 114-123 (1982).

Fatokun, A.A., V.L Dawson and T.M. Dawson: Parthanatos: mitochondria linked mechanisms and therapeutic opportunities. Brit. J. Pharmacol., 171, 2000-2016 (2014).

Fleckenstein, A., J. Janke, H.J. Doring, and O. Leder: Myocardial b=fibre necrosis due to intracellular calcium overload a new principle in cardiac pathophysiology. REc. Adv. Stud. Card. Struct. Metab., 4, 563-580 (1974).

Flohe, L., W.A. Gunzler and H.H. Schock: Glutathione peroxidase: A selenoenzyme. FEBS Lett., 32, 132-134(1973).

Florey, O., E. Kim and M. Overholtzer: Entosis: Cell-in-cell formation that kills through entotic cell death. Curr. Mol. Med., 15, 861-866 (2015).

Franchi, L., T. Eigenbrod, R.M. Planillo and G. Nunez: The inflammasome: A caspase 1 activation platform that regulates immune responses and disease pathogenesis. Nat. Immunol., 10, 241-274 (2009).

Friedman-Angeli, J.P.: Inactivation of the ferroptosis regulator GPx4 triggers acute renal failure in mice. Nat. Cell Biol., 16, 1180-1191 (2014).

Galluzzi, L., I.Vittale and G.Kroemer et al.: Molecular mechanisms of cell death: Recommendations of the nomenclature committee on cell death 2018. Cell Death Differ., 25, 486-541 (2018).

Gillette, J.R., J.R. Mitchell and B.B. Brodie: Biochemical basis for drug toxicity. Annu. Rev. Pharmacol Toxicol., 14, 271-288 (1974).

Guengerich, F.P.: Common and uncommon cytochrome P450 reactions related metabolism and chemical toxicity. Chem Res Toxicol., 14, $611-650$ (2001).

Halliwell, B and J. Gutteridge: Free radicals in biology and medicine., Oxford University Press (1985).

Hamadeh, H.K. and C.A. Afshari: Toxicogenomics: Principles and Applications. Wiley Interscience. (2004).

Hayflick, L. and P.S. Moorhead: The serial cultivation of human diploid cell strains. Exp Cell Res., 25, 585-62 (1961).

$\mathrm{He}, \mathrm{S}$. and N.E. Sharpless: Senescence in health and disease. Cell., 169, 1000-1011(2017).

Hetz, C., E. Chevet and H.P. Handing: Targeting the unfolded protein response in disease. Nat Rev Drug Discovery., 12, 703-719 (2013).

Heo, S.H., J.H. Oh, H.J. Park, M.S. Kwon, S.V.S. Rana and S.J. Yoon: Toxicoproteomic analysis of phalloidin induced cholestasis in mouse liver. Mol. Cell. Toxicol., 6, 87-95(2010).
Hofmans, S., T.V. Berghe, L. Devisscher, B. Hassannia, S. Lyssens, J. Joossens, P.V.D. Veken, P. Vandenabeele and K. Augustyns: Novel ferroptosis inhibitors with improved potency and ADME properties. J. Med. Chem., 54, 2041-2053 (2016).

Jakoby, W.B.: Enzymatic basis of detoxication. Vol 1 \& 2. Elsevier Biomedical Press, Amsterdam.(1980).

Jeong, S.Y., J.S. Lim, H.J. Park, J.W. Cho, S.V.S. Rana and S. Yoon: Effect of acetaminophen on hepatic gene expression in mice. Physiol Chem. Phys. Med. NMR., 38, 77-83 (2006).

Jones, D.P. and H. Sies: The redox code. Antioxi. Rdox. cycl., 23, 734$746(2015)$

Jorgensen, I. And E.A. Miao: Pyroptotic cell death defends against intracellular pathogens. Immunol Rev., 265, 130-142 (2015).

Kayagaki, N., I.B. Stowe, B.L. Lee, K. O'Rourke, K. Anderson, S. Warming, T. Cuellar, B. Haley, M. Roose-Girma, Q.T. Phung, P.S. Liu, J.R. Lill, H. Li, J. Wu, S. Kummerfeld, J. Zhang, W.P. Lee, S.J. Snipas, G.S. Salvesen, L.X. Morris, L. Fitzgerald, Y. Zhang, E.M. Bertram, C.C. Goodnow and V.M. Dixit: Caspase 11 cleaves gasmerdin $D$ for non cannonical inflammasome signalling. Nature., 526, 666-671(2015).

Keppler, D.: Pathogenesis and mechanisms of liver cell necrosis. Springer Verlag (1975).

Kim, J. and B.J. Padamilam: Loss of poly (ADP-ribose) polymerase - I attenuates renal fibrosis and inflammation during unilateral ureteral obstruction. Am. J. Physiol. Renal. Physiol., 301, 450-459 (2011).

Kim, S.E. and M. Overholtzer: Autophagy proteins regulate cell engulfment mechanism that participate in cancer. Sem Cancer Biol., 23, 329-336 (2013).

Kimura, $\mathrm{H}$.: Physiological role of hydrogen sulphide and polysulfide in the central nervous system. Neurochem International., 63, 492-497 (2013).

Kimura, H.: Signalling molecules: Hydrogen sulphide and polysulfide. Antioxid. Redox. Signal., 22, 362-376 (2015).

Klaassen, C.D., J. Liu and S. Choudhuri: Metallothionein: an intracellular protein to protect against cadmium toxicity. Annu. Rev. Pharmacol. Toxicol., 39, 267-294 (1999).

Klingenberg, M.: Pigments of rat liver microsomes. Arch. Biochem. Biophys., 75, 376-386 (1958).

Kosower, E.M. and N.S. Kosower: Disorders in glutathione metabolism. Nature (London)., 224, 117-120 (1969).

Kotschy, A., Z. Szlavik, J. Murray, J. Davidson, A.L. Maragno, G. Le Toumelin-Braizat, M. Chanrion, G.L. Kelly, J.N. Gong, D.M. Moujalled, A. Bruno, M. Csekei, A. Paczal, Z.B. Szabo, S. Sipos, G. Radics, A. Proszenyak, B. Balint, L. Ondi, G. Blasko, A. Robertson, A. Surgenor, P. Dokurno, I. Chen, N. Matassova, J. Smith, C. Pedder, C. Graham, A. Studeny, G. Lysiak-Auvity, A.M. Girard, F. Gravé, D. Segal, C.D. Riffkin, G. Pomilio, L.C.A. Galbraith, B.J. Aubrey, M.S. Brennan, M.J. Herold, C. Chang, G. Guasconi, N. Cauquil, F. Melchiore, N.G. Stephan, B. Lockhart, F. Colland, J.A. Hickman, A.W. Roberts, D.C.S. Huang, A.H. Wei, A. Strasser, G. Lessene and O. Geneste: The MCL1 inhibitor $\$ 63845$ is tolerable and effective in diverse cancer models. Nature., 538, 477-482 (2016).

Krishna, S. and M. Overholtzer: Mechanisms and consequences of entosis. Cell Mol Life Sci., 73, 2379-86 (2016).

Krishna, S., W. Palm, Y. Lee, W. Yang, U. Bandyopadhyay, H. Xu, O. Florey, C.B. Thompson and M. Overholtzer: PIKfye regulates 
vacuole maturation and nutrient recovery following engulfment. Dev. Cell., 38, 536-547 (2016).

Kurz, T., A. Terman, B. Gustaffson and U.T. Brunk: Lysosomes and oxidative stress in ageing and apoptosis. Biochim. Biophys. Acta., 1780, 1291-1303 (2008).

Leonard, J.P. and M.M. Salpeter: Agonist-induced myopathy at the neuromuscular junction is mediated by calcium. J. Cell Biol., 82, 811-819(1979).

Linossier, G.: Contribution a l'etude des ferments oxidants Sur la peroxidase du pups. C. R. Soc. Biol. Paris., 50, 373-375(1898).

Liu, Y., S.S. Kawata, R.M. Sumpter Jr., Y. Wei, V. Ginet, L. Zhang, B. Posner, K.A .Tran, D.R. Green, R.J. Xavier, S.Y. Shaw, P.G.H. Clarke, J. Puyal and B. Levine: Autosis is a $\mathrm{Na}^{+}, \mathrm{K}^{+}$-ATPase regulated form of cell death triggered by autophagy - inducing peptides, starvation and hypoxia-ischemia. Proc. Nat. Acad. Sci. (USA)., 110, 20364-71 (2013).

Lim, J.S., S.Y. Jeong, J.Y. Hwang, H.J. Park, Y.B. Kim, S.V.S. Rana and S. Yoon: Effect of phalloidin on hepatic gene expression in mice. Int. J. Toxicol., 26, 213-220 (2007).

Lockard, V.G., H.M. Mehendale and R.M. O'Neal: Chlordecone-induced potentiation of carbon tetrachloride hepatotoxicity: A morphometric and biochemical study. Exp. Mol. Pathol., 39, 246255 (1983).

Lockshin, R.A.: Programmed cell death. Activation of lysis of a mechanism involving the synthesis of protein. J. Insect. Physiol., 15, 1505-1512 (1969).

Lood, C., L.P. Blanco, M.M. Purmalek, C.C. Rivera, S.S. De Ravin, C.K. Smith, H.L. Malech, J.A. Ledbetter, K.B. Elkon and M.J. Kaplan: Neutrophil extracellular traps enriched in oxidized mitochondrial DNA are interferogenic and contribute to lipus-lke disease. Nat. Med., 22, 146-153 (2016).

Luz, A.L., T.R. Godebo, L.L. Smith, T.C. Leuthner, L.L. Maurer and J.N. Meyer: Deficiencies in mitochondrial dynamics sensitize Caenorhabditis elegans to arsenite and other mitochondrial toxicants by reducing mitochondrial adaptability. Toxicology, 387, 81-94(2017).

Malhi, H. and R.J. Kaufman: Endoplasmic reticulum stress in liver disease. J. Hepatol., 54, 795-809 (2011).

Margoshe, M. and B.L. Vallee: An cadmium protein from equine kidney cortex. J. Amer. Chem. Soc., 79, 4813-4814 (1957).

Martin, D.P., R.E. Schmidt, P. DiStefano, O.H. Lowry, J.G. Carter and E. Johnson: Inhibitors of protein synthesis and RNA synthesis prevent neuronal death caused by nerve growth factor deprivation. J. Cell. Biol., 106, 829-844 (1988).

McCord, J.M. and I. Fridovich: Superoxide dismutase: An enzymatic function for erythrocuprein (hemocuprein). The $\mathrm{J}$ of Biol Chem., 244, 6049-6055 (1969).

Mehendale, H.M., K.N. Thakore and C.V. Rao: Autoprotection: stimulated tissue repair permits recovery from injury. J. Biochem. Toxicol., 9, 131-139(1994).

Meyer, J.N., M.C.K. Leung, J.P. Rooney, A. Sendoel, M.O. Hengartner, G.E. Kisby and A.S. Bess: Mitochondria as a target of environmental toxicants. Toxicol. Sci., 134, 1-17 (2013).

Meyer, J.N. and S.S.L. Chan: Sources, mechanisms and consequences of chemical induced mitochondrial toxicity. Toxicology., 391 (2017). doi.10.1016/j.tox.2017.06.002.

Miao, L. and D.K.S. Clair: Regulation of superoxide dismutase genes: Implications in disease. Free Rad. Biol. Med., 47, 344-356 (2009).
Michaelson, J.: Cell selection in development. Biol Rev., 62, 115-139 (1987).

Munck, A.: Glucocorticoid inhibition of glucose uptake by peripheral tissues: old and new evidence, molecular mechanisms, and physiological significance. Perspect. Biol. Med., 14, 265-289 (1971).

Niki, E., E. Komuro, M. Takahashi, S. Urano, E. Ito and K. Terao: Oxidative hemolysis of erythrocytes and its inhibition by free radical scavengers. J. Biol. Chem., 263, 19809-19814 (1988).

Ogata, M., D. Wang and K. Ogino: Mammalian acatalasemia: The perspectives of bioinformatics and genetic toxicology. Acta. Med. Okayama, 62, 345-361 (2008).

Ogata, M.: Acatalasemia. Hum. Genetics., 86, 331-340 (1991)

Ogeturk, M., I. Kus, A. Kavakli, I. Zararsiz, N. Ilhan and M. Sarsilmaz: Effect of melatonin on carbon tetrachloride induced changes in the serum. J. Physiol. Biochem., 60, 205-210 (2004).

Omura, T. and R. Sato: The carbon monoxide binding pigment of liver microsomes. I Evidence for its hemoprotein nature. J. Biol. Chem., 239, 2370-2378 (1964).

Oppenheim, R.W., D. Prevette, M. Tytell and S. Homma: Naturally occurring and induced neuronal death in the chick embryo in vivo requires protein and RNA synthesis. Evidence for the role of cell death genes. Dev. Biol., 138, 104-113(1990)

Oronsky, B., N. Oronsky, J. Sacinsky, G. Fanger, M. Lybeck and T. Reid: Rewriting the epigenetic code for tumor sensitization-A review. Trans. Oncol., 7, 626-631 (2014).

Orrenius, S.: On the mechanism of drug hydroxylation in rat liver microsomes. J. Cell. Biol., 26, 713-723 (1965).

Orrenius, S., P. Nicotera and B. Zhivotovsky: Cell death mechanisms and their implications in toxicology. Toxicol Sci., 119, 3-19 (2011).

Orrenius, S., B. Zhivotovsky and P. Nicotera: Regulation of cell death: the calcium apoptosis link. Nat Rev Mol Cell Biol., 4, 552-565 (2003).

Orrenius, S. and B. Zhivotovsky: The future of toxicology-does it matter how cells die. Chem Res Toxicol., 19, 729-733 (2006).

Orrenius, S.: Reactive oxygen species in mitochondria mediated cell death. Drug Metab. Reviews., 39, 443-455 (2007).

Orrenius, S., V. Gogvadze and B. Zhivotovsky: Mitochondral oxidative stress: implication for cell death. Annu. Rev. Pharmacol. Toxicol., 47, 143-183 (2007).

Orrenius, S.: Role of cell death in toxicology: Does it matter how cells die. Annu. Rev. Pharmacol. Toxicol., 59, 1-14 (2019).

Overholtzer, M., A.A. Mailleux, G. Mouneimne, G. Normand, S.J. Schnitt, R.W. King, E.S. Cibas and J.S. Brugge: A non apoptotic cell death process, entosis that occurs by cell-in-cell invasion. Cell., 131, 966-979 (2007).

Papp, L.V., J. Lu, A. Holmgren and K.K. Khanna: From selenium to selenoproteins, synthesis, identity and their role in human health. Antioxid. Redox. Signal., 9, 775-804 (2007).

Park, H.J., J.H. Oh, S. Yoon and S.V.S. Rana: Time dependent gene expression changes in the liver of mice treated with benzene. Biomarker. Insights., 3, 191-201 (2008).

Patergnani, S., J.M. Suski, C. Agnoletto, A. Bononi, M. Bonora, E. De Marchi, C. Giorgi, S. Marchi, S. Missiroli, F. Poletti, A. Rimessi, J. Duszynski, M.R. Wieckowski and P. Pinton: Calcium signalling around mitochondria associated membranes (MAMs). Cell Commun.Signal., 9, Article number 19, (2011).

Plaa,G.L.: Chlorinated methanes and liver injury: Highlights of the fast 50 years. Annu. Rev. Pharmacol. Toxicol., 40 , 43-65 (2000). 
Popper, H. and F. Schaffner: Liver: Structure and Function. McGraw Hill New York, 1957, pp 777.

Rana, S.V.S. and A. Kumar: Metallothionein induced by cadmium or zinc inhibits lipid peroxidation in rat exposed to dimethylnitrosamine. Arh Hig Rada Toksikol., 51, 279-286 (2000).

Rana, S.V.S. and A. Kumar: Effect of cadmium and zinc metallothionein on methemoglobin and nitric oxide in dimethylnitrosamine treated rat. Ind. J. Exp. Biol., 39, 487-489 (2001).

Rana, S.V.S. and A. Chauhan: Alleviation of lipidperoxidation in liver and kidney of molybdenotic rats by methione and zinc. Environ. Nutr. Unteract., 2, 1520-1524 (1998).

Rana, S.V.S. and S. Rastogi: Effect of parathyroidectomy on calcium and phospholipase A2 in the liver of carbontetrachloride treated rat. Physiol. Chem. Phys. Med. NMR., 23, 173-176 (1991).

Rana, S.V.S. and S. Kumar: Effect of sex hormones on lipid peroxidation in the necrotic liver of rat. Gegenbaurs. Morphol. Jahrb., 133, 657$663(1987)$.

Rana, S.V.S., R. Singh and S. Verma: Protective effects of GSH, vitamin $\mathrm{E}$ and selenium on lipid peroxidation in cadmium fed rats. Biol. Trace. Elem. Res., 51,161-168 (1997).

Rana, S.V.S. and S. Verma: Protective effects of GSH, a tocopherol and selenium on lipid peroxidation in liver and kidney of copperfed rat. Bull. Environ. Cont. Toxicol., 59, 152-158 (1997).

Rana, S V S and Y. Verma: Sex differences in oxidative stress induced by benzene in rats. Ind. J. Exp. Biol., 42, 117-120 (2004).

Rana, S.V.S., R. Singh and S. Verma: Mercury- induced lipid peroxidation in liver, kidney, brain and gills of fresh water fish, Channa punctatus. Jap. J. Ichthyology, 42, 255-259 (1995).

Rana, S.V.S.: Protection of metal toxicity by melatonin-recent advances. EC Pharmacol. Toxicol., 6, 851-864 (2018).

Rana, S.V.S., N. Chaudhary and Y. Verma: Circadian variation in lipid peroxidation induced by benzene in rat. Indian J. Exp. Biol., 45, 253-257 (2007).

Rana, S.V.S. and V.P. Agrawal: Histochemical studies of a few enzymes in the liver of common ground squirrel treated with carbon tetrachloride. Acta Histochem., 41, 125-130 (1971).

Rana, S.V.S. and P.R. Boora: Antiperoxidative mechanisms offered by selenium against liver injury caused by cadmium and mercury in rat. Bull. Environ. Cont. Toxicol., 48, 120-124 (1992).

Rana, S.V.S. and M.K. Tayal: Infuence of zinc, vitamin $B_{12}$ and glutathione on the liver of rats exposed to carbon tetrachloride. Indus. Hith. (Japan)., 19, 65-69 (1981).

Rana, S.V.S. and M.K. Tayal: Lipotropic effects of vitamin $B_{12}$, glutathione and zinc. A comparative histochemical study in the liver of carbon tetrachloride poisoned rats. Mikroskopie., 38, 294-300 (1981).

Rana, S.V.S. and N. Rastogi: Antioxidant enzymes in the liver and kidney of alloxan induced diabetic rats and their implications in cadmium toxicity. Physiol. Chem. Phys. Med. NMR., 32, 67-74 (2000).

Rana, S.V.S. and S. Kumar: Antioxidative enzymes in the liver of rat after individual and combined exposure to xylene, toluene and methyl alcohol. Physiol. Chem. Phys. Med. NMR., 27, 25-29 (1995).

Rana, S.V.S. and S. Kumar: Lipid peroxidation in liver, kidney and brain of rat after combined exposure to xylene, toluene and methyl alcohol. Indian J. Exp. Biol., 32, 919-921 (1994).

Rana, S.V.S. and S. Rastogi: Antioxidative enzymes in the liver of rat treated with carbon tetrachloride after parathyroidectomy. Physiol. Chem. Phys. Med. NMR., 25, 41-47 (1993).

Rana, S.V.S., T. Allen and R. Singh: Inevitable glutathione, then and now.
Ind. J. Exp. Biol., 40, 706-716 (2002).

Rana, S.V.S.: Oxidative stress and liver injury by environmental xenobiotics. In : Liver and Environmental Xenobiotics (Eds.: S.V.S. Rana and K. Taketa) Springer Verlag. Berlin, Heidelberg and New York. pp. 114-134(1997).

Rana, S.V.S.: Lipids in the liver of squirrel after carbon tetrachloride treatment. Acta Histochem., 51, 214-219(1974).

Rana, S.V.S.: Simultaneous protective effects of a new chelating agent and zinc on carbon tetrachloride induced hepatic injury in squirrel. Res. Exp. Med., 170, 217-227 (1977).

Rana, S.V.S. and S. Gupta: Metabolism of toluene and trichloroethylene in laboratory rat pretreated with phenobarbital. J. Env. Biol., 21, 26 (2000).

Rana, K., Y. Verma and S.V.S. Rana: Renal toxicity of nanoparticles of cadmium sulphide in rat. Chemosphere., 193, 142-150 (2018).

Rani, V., Y. Verma, K. Rana and S.V.S. Rana: Zinc oxide nanoparticles inhibit dimetyhlnitrosamine induced liver injury in rat. Chem. Biol. Interact., 295, 84-92 (2018).

Rana, S.V.S., T. Allen and R. Singh: Inevitable glutathione, then and now. Indian J Exp Biol., 40, 706-716 (2002).

Rana, S.V.S. and R. Singh: Species differences in glutathione dependent enzymes in the liver and kidney of two fresh water fish and their implications in cadmium toxicity. Ichthylog. Res., 43, 223-229 (1996).

Rana, S.V.S.: Metals and apoptosis- recent developments. J. Trace. Elem. Med. Biol., 22, 262-284 (2008).

Rana, S.V.S.: Endoplasmic reticulum stress by toxic elements- a review of recent developments. Biol .Trace. Elem. Res., 196, 10-19 (2020).

Recknagel, R.O. and A.K. Ghoshal: Lipid peroxidation as a vector in carbon tetrachloride hepatotoxicity. Lab. Invest., 15, 132-148 (1966).

Recknagel, R.O.: Carbon tetrachloride hepatotoxicity. Pharmacol. Rev. 19, 145-208 (1967).

Recknagel, R.O., E.A. Jr Gelende., R.L. Waller and K. Lowrey: Lipid peroxidation: Biochemistry. Measurement and significance in liver cell injury. In : Toxicology of the liver ( Eds.: G.L.Plaa and W.R. Hewitt). Raven Press, New York. pp 213-241 (1982).

Reddy, J.K., N. Usuda., Q. Huang and M.S. Rao: Histochemistry of peroxisomes: overview. Acta Histochem. Cytochem., 28, 165-167 (1995).

Reiter, R.J.: The pineal and its hormones in the control of reproduction in mammals. Endocr. Rev., 1, 109-131 (1980).

Remijsen, Q., T.V. Berghe, E. Wirawan, B. Asselbergh, E. Parthoens, R. De Rycke, S. Noppen, M. Delforge, J. Willems and P. Vandenabeele: Neutrophil extracellular trap cell death requies both autophagy and superoxide generation. Cell Res., 21, 290304 (2011).

Roos, W.P., A.D. Thomas and B. Kaina: DNA damage and the balance between survival and death in cancer biology. Nat. Rev. Cancer., 16, 20-33 (2016)

Rotruck, J.T., A.L. Pope, H.E. Gunther, A.B. Swanson, D.G. Hafeman and W.G. Hoekstra: Selenium: Biochemical role as a component of glytathione peroxidase. Science, 179, 588-590 (1973).

Rouiller, C.: Experimental toxic injury of the liver. In: The Liver Morphology, Biochemistry and Physiology. Vol-II (Ed.: F.W. Hoffbauer). Academic Press London and New York, pp. 335-476 (1964).

Santos, C.X.C., L.Y. Tanaka, J. Wosniak and F.R.M. Laurindo: 
Mechanisms and implications of reactive oxygen species generation during unfolded protein response: Role of endoplasmic reticulum oxido-reductase, mitochondrial electron transport and NADPH oxidase. Antiox. Redox. Signal., 11, 2409-2427(2009).

Semenza, G.L.: Involvement of hypoxia inducible factor 1 (HIF1) in pulmonary pathophysiology. Chest., 128, 592S-594S (2005).

Semenza, G.L.: Life with oxygen. Science., 318, 62-64 (2007)

Schellenberg, B., P. Wang, J. A Keeble, R. Rodriguez-Enriquez, S. Walker, T. W. Owens, F. Foster, J. Tanianis-Hughes, K. Brennan, C. H. Streuli and A. P. Gilmore: Bax exists in a dynamic equilibrium between the cytosol and mitochondria to control apoptotic priming. Mol. Cell., 59, 959-971 (2013).

Schnbein, C.F.: Ueber die katalytische Wirksamkeit organischer Materien und deren Vebreitung in der Pflanzen und Thierwelt. $J$ Prakt. Chem., 89, 323-344(1863).

Seiler, A., M. Schneider, H. Forster, S. Roth, E.K. Wirth, C. Culmsee, N. Plesnila, E. Kremmer, O. Rådmark, W. Wurst, G.W. Bornkamm, U. Schweizer and M. Conrad: Glutathione peroxidase 4 senses and translates oxidative stress into 12/15 lipoxygenase dependent and AIF mediated cell death. Cell Metab., 8, 237-248 (2008).

Serrano-Puebla, A. and P. Boya: Lysosomal membrane permeabilization in cell death: new evidence and implications for health and disease. Ann. N. Y.Acad. Sci., 1371, 30-44 (2016).

Sharma, S. and S.V.S. Rana: Melatonin improves liver function in benzene treated rats. Arh. Hig. Rada. Toksikol., 64, 33-41 (2013).

Sharma, S. and S.V.S. Rana: Melatonin inhibits benzene induced lipid peroxidation in rat liver. Arh. Hig. Rada. Toksikol., 61, 11-18 (2010).

Sharpless, N.E. and J. Sherr: Forging a signature of in vivo senescence. Nat. Rev. Cancer., 15, 397-408 (2015).

Shimamoto, N.: A pathophysiological role of cytochrome $\mathrm{P}_{450}$ involved in production of reactive oxygen species. Yakugaku Zasshi., 133, 435-450 (2013).

Sies, $\mathrm{H}$. and A. Wendel: Functions of glutathione in liver and kidney. Springer Verlag, Berlin, Heidelberg and New York, p. 214 (1978).

Sies,H. and K.H. Summer: Hydroperoxide metabolizing system in rat liver. Eur. J. Biochem., 57, 503-512 (1975).

Sies, H.: Biochemistry of oxidative stress. Angew. Chem. Int. Ed. Engl., 25, 1058-1071 (1986).

Sies, H. and D.P. Jones: Oxidative stress: In: Encyclopaedia of Stress (Eds.: G. Fink). Elsevier. pp. 45-47 (2007).

Singh, R. and S.V.S. Rana: Influence of antioxidants on metallothionein mediated protection in cadmium fed rats. Biol. Trace. Elem. Res., 88, 71-77 (2002).

Slater, T.F.: Biochemical Mechanisms of Liver Injury. Academic Press, London and New York. (1978).

Sohini and S.V.S. Rana:Ascorbic acid improves mitochondrial function in liver of arsenic treated rat. Toxicol Ind Health., 26, 265-272 (2010).

Sohini and S.V.S. Rana: Protective effect of ascorbic acid against oxidative stress induced by inorganic arsenic in liver and kidney of rat. Ind. J. Exp. Biol., 45, 371-375 (2007).

Sun, Q., T. Luo, Y. Ren, O. Florey, S. Shirasawa, T. Sasazuki, D.N. Robinson and M. Overholtzer: Competition between human cells by entosis. Cell Res., 24, 1299-1310 (2014).

Sumoza-Toledo, A. and R. Penner: TRPM2 multifunctional iron channel calcium signalling. J. Physiol., 589, 1515-1525 (2011).

Tait, S.W. and D.R. Green: Mitochondria and cell death: Outer membrane permeabilization and beyond. Nat Rev Mol Cell Biol., 11, 621-632 (2010).
Tappel, A.L.: Lipid peroxidation damage to cell components. Fed Proc., 32, 870-874 (1973).

Thomas-Zapico, C. and A. Coto-Montes: A proposed mechanism to explain the stimulatory effect of melatonin on antioxidant enzymes. J. Pineal. Res., 39, 99-104 (2005).

Till, J.E.: Cellular diversity in the blood forming system. Am Sci., 69, 522527 (1981).

Todt, F., Z. Cakir, F. Reichenbach, F. Emschermann, J. Lauterwasser, A. Kaiser, G. Ichim, S.W.G. Tait, S. Frank, H.F. Langer and F. Edlich: Differential translocation of mitochondrial Bak and Bax. EMBO J., $34,67-80$ (2015).

Trump, B.F. and I.K. Berezwsky: Calcium mediated cell injury and cell death. FASEB J., 9, 219-228 (1995).

Ucker, D.S., J.D. Ashwell and G. Nickas: Activation - driven T cell death. I. Requirements for de novo transcription and translation and association with genome fragmentation. J. Immunol., 143, 34613469(1989).

Valente, W.J., N.G. Ericson, A.S. Long, P.A. White, F. Marchetti and J.H. Bielas: Mitocondrial DNA exhibits resistance to induced point and deletion mutations. NucleicAdid Res., 44, 8513-8524(2016).

Van Deursen, J.M.: The role of senescent cells in ageing. Nature., 509, 439-446 (2014).

Vandangenakker, N., T.V. Berghe. and D.V. Krysko et al: Molecular mechanisms and pathophysiology of cell death. Curr. Mol. Med., 8, 207-220 (2008).

Vanden Berghe, T., D. Demon, P. Bogaert, B. Vandendriessche, A. Goethals, B. Depuydt, M. Vuylsteke, R. Roelandt, E.V. Wonterghem, J. Vandenbroecke, S.M. Choi, E. Meyer, S. Krautwald, W. Declercq, N. Takahashi, A. Cauwels and P. Vandenabeele: Simultaneous targeting of $\mathrm{IL}-1$ and $\mathrm{LL}-18$ is required for protection against inflammatory and septic shock. Am. J. Respir. Crit. Care Med., 189, 282-291 (2014).

Vanden Berghe, T., A. Linkermann, S.J. Lanhouet, H. Walczak and P. Vandenabeele: Regulated necrosis: The expanding net work of non apoptotic cell death pathways. Nat. Rev. Mol. Cell Biol., 15, 135-147 (2014).

Vandennabelle, P., L. Galuzzi, T.V. Berghe and G. Kroemer: Molecular mechanisms of necroptosis: An ordered cellular explosion. Nat. Rev. Mol. Cell. Biol., 11, $700-714$ (2010).

Verma, Y. and S.V.S. Rana: Sex differences in oxidative stress induced by benzene in rat. Ind. J. Exp. Biol., 42, 117-120 (2004).

Wan, Q., J. Liu, Z. Zheng, H. Zhu, X. Chu, Z. Dong, S. Huang and Q. Du: Regulation of myosin activation during cell-in -cell contact formation by Par3-1g1 antagonism: entosis without matrix detachment. Mol Biol Cell., 23, 2076-2091 (2012).

Wang, S. and R.J. Kaufman: The impact of the unfolded protein response on human diseases. J. Cell Biol., 197, 857-867 (2012).

Wyllie, A.H.: Glucocorticoid induced thymocytic apoptosis is associated with endogenous endonuclease activation. Nature., 284, 555-556 (1980).

Xie, Y., W. Hou, X. Song, Y. Yu, J. Huang, X. Sun, R. Kang and D. Tang: Ferroptosis. Process and function. Cell Death Differ., 23, 369-379 (2016).

Yamazaki, H.: Fifty years of cytochrome P450 research. Springer Verlag (2014). 10.1007/978-4-431-54992-5

Yang, W.S. and B.R. Stockwell: Ferroptosis: Death by lipid peroxidation. Trends Cell Biol., 26, 165-176 (2016).

Yang, W.S. and B.R. Stockwell: Synthetic legal screening identifies 
compounds activating iron dependent non apoptotic cell death in oncogenic RAS harbouring cancer cells. Chem. Biol., 15, 234-245 (2008).

Yoon, S.J., S.S. Han and S.V.S. Rana: Health risk assessment of exposure to industrial solvents through molecular markers. A review. J. Ecophysiol. Occup. Hlth., 6, 89-104 (2007).

Yoon, S.J., S.S. Han and S.V.S. Rana: Molecular markers of heavy metal toxicity- a new paradigm for health risk assessment. J. Env. Biol., 29, 1-14 (2008).

Yousefi, S., R. Perozzo, I. Schmid, A. Ziemiecki, T. Schaffner, L. Scapozza, T. Brunner and H.U. Simon: Calpain mediated cleavage of Atg5 switches autophagy to apoptosis. Nat. Cell Biol., 8, 11241132 (2006).
Yousefi, S., C. Mihalache, E. Kozlowski, I. Schmid and H.U. Simon: Viable neutrophils release mitochondrial DNA to form neutrophil extracellular traps. Cell Death Differ., 16, 1438-1444 (2009).

Yu, S.W., H. Wang, M.F. Poitras, C. Coombs, W.J. Bowers, H.J. Federoff, G.G. Poirier, T.M. Dawson and V.L. Dawson: Mediation of poly (ADP-ribose) polymerase-I dependent cell death by apoptosis inducing factor. Science., 297, 259-263 (2002).

Zimmerman, H.J. Hepatotoxicity: The adverse effects of drugs and other chemicals on the liver. New York : Appleton-Century-Crofts, p. 597 (1978).

Zglinicki, T.V., T. Wan and S. Miwa: Senescence in post - mitotic cells: A driver of ageing? Antioxid Redox Signal., 34, 308-323 (2021). 